\title{
Banking Sustainability in Indonesia
}

\author{
Maryanti $^{1}$, Febriandi Prima Putra ${ }^{2}$, Edi Ariyanto ${ }^{3}$, Anas Iswanto Anwar ${ }^{4}$ \\ Faculty Economy Andalas University ${ }^{1,2,3}$, \\ Faculty Economic and Business Hasanuddin University ${ }^{4}$ \\ \{maryantiandriko@gmail.com ${ }^{1}$, febriandipp@gmail.com², ediariyanto@gmail.com ${ }^{3}$, \\ anasiswantoanwar@fe.unhas.ac.id $\left.{ }^{4}\right\}$
}

\begin{abstract}
Sustainable banking is a forefront of sustainable development. The intermediation function in the banking industry is in a unique position in sustainable development. This paper embodies the initiatives taken by the banking industry regulatory authorities in Indonesia in sustainable development. The study explore sustainable banking which includes Financial Inclusion (FI), Corporate Social Responsibility (CSR), and Green Banking (GB). The study results show a positive response in implementing sustainable banking issues under the guidance of Bank Indonesia as the central bank. The result studies are expected to reveal banking and policy making regarding the concept of sustainable banking on sustainable development in Indonesia.
\end{abstract}

Keywords: Sustainability Development; Financial Institution; Corporate Social Responsibility; Green Banking

\section{Introduction}

Sustainable development is an indicator of the success of development including economic, social and environmental aspects. Because economic development requires natural and environmental resources that will solve development problems in the future (Maryanti, 2020). The banking industry is in a unique position in sustainable development because it has an intermediary function between depositors and borrowers. Sustainability is increasingly being recognized as the center of growth for emerging market economies. For the banking sector, this represents a position of demand for greater social and environmental responsibility and a new landscape of business opportunities. Today, banks are starting to realize the big impact of sustainable development on the hidden ways of developing society and, implicitly, on the way to create banking value in the future.

Banking which includes commercial and investment banks and microfinance institutions is united by the fact that they mediate financial flows by borrowing funds from individual or organizational depositors and channeling these financial resources to individual or corporate borrowers, mainly in the form of business and commercial loans. They offer financial services to their customers on a short term basis and charge a fee for providing their financial resources. They also perform a more intensive intermediary role for the economy by minimizing risk and finding strategic ways to attract customers, which are their main business goals (Roy, 2015).

In Indonesia, banking plays an important role in the development of the country's economy. They are relentlessly trying to develop innovative financial products and provide better services to their clients to ensure higher profitability. They need to find sustainable ways of getting high-profit businesses to satisfy their shareholders. They are familiar with 
several sustainable products \& services such as green banking, environmental risk ratings in the credit assessment process, diversified savings \& credit base for banks through financial inclusion, technological advances in banking operations, mobile banking, and others. They can also enhance their internal cost-saving strategy, which can drive sustainability. They have also been able to compile internal guidelines and management systems to prevent losses due to sustainability issues in financing (Abubakar \& Tri Handayani, 2019). When investors, consumers, and businesses wish to invest in sustainability, banks develop products that meet their requirements (Jeucken, 2004). Thus, the development of a banking management system based on sustainable principles is one of the current provocations.

The problem to be achieved is how do banks contribute in implementing the principles of sustainable finance in Indonesia? This will be analyzed descriptively on the sustainability performance of banking in Indonesia. The main problem in this paper is the role of banks in implementing the three pillars of sustainability, namely economic, social, and environmental aspects without abandoning the principles of sustainable finance that adhere to risk minimization and financial transparency. To study and analyze it is not an easy thing. Therefore, in this study the analysis will be focused on the sustainable financial reports of banks by taking into account economic aspects, namely financial inclusion (FI), social aspects, namely corporate social responsibility (CSR), and environmental aspects, namely green banking (GB).

\section{Literature Review}

Banks play a central role in mediating capital and assets between the surplus and deficit in household spending throughout the economy (Cull et al., 2013). They bear a big responsibility for sustainable development (Scholtens, 2017; Galaz et al., 2018). Mark Carney, governor of the Bank of England, pointed out that climate change is a major concern for the financial industry (Carney, 2015).

The potential risk of bank default in the financial system has an impact on systemic sustainability (bank risk) (Homer-Dixit et al, 2015; Keys et al 2019). Systemic sustainability is a human-driven process interacting with socio-ecological connectivity (Galaz et al., 2018). Then, its relevance to society plays a role when a banking case occurs (Berger et al., 2017).

The banking industry focuses on the sustainability of their production and their position in the economic chain (Dafermos et al, 2018; Kemp-Benedict, 2018). The banking sector plays an important role in economic transformation, which implies sustainable accounting to reduce the external (unpaid) economic effects of the production process (Heal, 2008).

Economic systems directly affect sustainability such as pollution, inequality due to the use of water, human capital and energy (Semenova \& Hessel, 2015; Dortfleitner et al, 2015). Sustainability in industry is proxied by the characteristics of environmental and social management (Friedge et al, 2015). As an intermediary in financial services, banking takes into account the environmental, social, government policies and company or organizational policies.

Several studies investigating sustainability in the financial industry, for example, Simpson \& Kohers, 2002 in the United States; Scholtens, 2007 in the Netherlands; Menassa, 2010 in Lebanon; Callado-Munoz \& Utreto-Gonzales, 2011 in Spain; Uddin et al, 2012 in Bangladesh; Saxena \& Kohli, 2012 in India; Kamal, 2013 in Egypt, Adewale \& Rahmon, 2014 in Nigeria; Malik \& Nadeem, 2014 in Pakistan; Paulik et al, 2015 in the Czech Republic. This literature shows variations in dealing with sustainability that result in better financial performance. 
When the global financial crisis occurred, it was discussed the sustainability of banks with social responsibility (Paulik et al, 2015; Cornett et al, 2016; Scholtens, 2019).

Researchers have revealed a close relationship between finance and sustainability (in relation to economic, social, and environmental issues (Cornett et al, 2016; Bouslah et al, 2018; Berger et al, 2017). They found a return on average assets (ROAA) relationship, and capital asset ratio (CAR) is related to sustainability (Laeven \& Levine, 2009; Berger et al, 2017). Several studies focus on financial, social, environmental risks (Sun \& Cui, 2014; Bouslah, 2018) which place risk as dependent variable which explains the sustainability variable.

Corporate Social Responsibility (CSR) is an embodiment of sustainable development because it is contained in the three pillars of sustainability in the social aspect (Lopata et al, 2016; Zahid \& Ghazali, 2015). This CSR refers to the balanced use of resources by incorporating economic, social and environmental needs without sacrificing the needs of future generations (Ong et al, 2016). Companies that practice sustainability can increase capital (Cheng et al, 2014; Loannou, 2015), reduce financing costs (Dhaliwal et al. 2011) reduce regulatory limits and achieve more profit (Brammer et al., 2008).

CSR practices in the banking industry cannot be separated from the business dimension in economic, social and environmental aspects (Hussain et al, 2016). This CSR practice reveals a way of life and work that is integrated with aspects of sustainability without destroying the needs of future generations (San, 2016).

In previous researchers who studied the CSR approach in the banking industry through the existence of the CSR index quality score (Hooks et al, 2011; Haniffa \& Cooke, 2005); Ghazali, 2007). The CSR index in the context of sustainability is mostly done in sustainability research (Haniffa \& Cooke, 2005). Comparison of the value of the CSR reporting index depends on the benefits received and reflects the responsibility of the company or organization in society (Unerman, 2000; Al-Tuwaijri, 2004).

Banks play a role in providing funding for projects and investments that can potentially cause environmental damage (Handajani, 2019). Thus, the role of banking becomes crucial by considering environmental issues in lending (Bryson et al, 2016) which identifies the factors that encourage banks to use green banking-based services which are considered green innovative practices and policies. Green innovation is an effective exploitation of new ideas to create environmental products, which can generate higher profit margins (Dangelico \& Pujari, 2010). The company's efforts to actively implement environmental-related ideas facilitate companies to develop new practices or products among competitors, reduce costs, seize opportunities and become market leaders (Bryson et al., 2016).

Several studies reveal the factors that encourage banks to practice green banking. The study of Bose et al. (2018) in testing banks in Bangladesh found that the guidelines for green banking regulations issued by the central bank have a positive impact on the level of green banking disclosure. Customer attention is also one of the factors that encourage green banking practices that can help banks develop marketing strategies in the context of green innovation (Bryson et al., 2016). These findings reveal that customer attention to using green banking products is influenced by integrity towards the environment, attitudes towards green banking, concern for the environment and collectivism.

However, a different study conducted by Ahmad et al., (2013) using factor analysis found that economic factors, policy guidelines, loans, stakeholder pressure and legal factors were factors that influenced the adoption of green banking by commercial banks to ensure sustainable economic development. Various arguments underlie the company's strategy in implementing green banking practices. Chen (2011) states that companies should improve 
their environmental organizational culture and environmental leadership to enhance the corporate green organizational identity and further to increase their green competitive advantage.

In connection with the bank's efforts to reveal issues related to green banking, banks are actually trying to gain legitimacy from regulators and the public. Several banks have used green banking as a powerful management tool because through the green banking report the company will get a green banking performance rating which will help improve the company's reputation (Hossain et al., 2016). It is further stated that green banking includes the bank's concern for the environment and other positive activities to conserve the environment and prevent environmental pollution.

However, green banking can also contribute to company performance. The empirical study of Ramiah et al (2016) found that investors will have the opportunity to get abnormal returns around environmental policy announcements. Thompson \& Cowton (2004) reveal that British banks incorporate environmental considerations into their corporate lending decisions by using developmental information sources in environmental reporting when making corporate lending decisions. Therefore, green banking has become a crucial factor in the management of banks today, thus becoming an important part of banking strategy.

\section{Result and Discussion}

\subsection{Public Bank Initiative on Sustainability Issues}

Based on policy of POJK No. 51 / POJK.03 / 2017 concerning sustainable finance requires all financial service institutions, including banks to apply the principles of sustainable finance. This principle accommodates to protect and improve the environment as well as to preserve; safeguard current and future natural resources, biodiversity, wetlands and wildlife. Thus sustainable development has become a constitutional obligation in Indonesia and sustainable banking is the front line of sustainable development through sustainable business.

At the end of 2014, the Financial Services Authority (OJK) launched the Sustainable Finance Roadmap. Sustainable finance is the real role of the Financial Services Institution to encourage sustainable growth (sustainable development) resulting from the harmony between economic interests (profit), social (people), and environment (planet) or known as 3P.

Specifically for the Financial Services Industry, the implementation of sustainable finance aims to increase the resilience and competitiveness of so that they can grow and develop in a sustainable manner; Providing the funding sources needed by the community referring to the National Medium Term Development Plan (RPJMN); and Contributing to the national commitment to the problem of global warming (global warming) through business activities that are mitigating and adapting to climate change towards a competitive low carbon economy.

The appreciation for the efforts that have been made by banks has encouraged the development and implementation of sustainable finance to support the implementation of Sustainable Development Goals (SDGs) in Indonesia. Banking initiatives to support the SDGs include the company's contribution in supporting sustainable development, which is reflected in the company's vision and mission, medium and long-term corporate strategy, financial performance, social and environmental responsibility, leadership and innovation, especially in its business activities so that it is aligned with values, 3P and implement Good Corporate Governance (GCG). 
Since 2016, a sustainable finance award (SFA) has been held, which is a form of banking initiative for the implementation of SDGs in banking in Indonesia. This SFA contains documents for the Company's Annual Report, a statement of the company's vision and mission, a company strategic plan for the next 3-5 years, a portfolio of environmentally friendly fund / investment / financing placements and a report on the implementation of Corporate Social Responsibility (CSR) and a Sustainability Report. Portfolio of environmentally friendly funds / investment / financing placements to business sectors such as clean and renewable energy (including hydro / solar / wind / biogas, biomass), energy efficiency, sustainable certified plantations (such as RSPO / ISPO for palm oil ), PROPER rating (Blue, Green, Gold), products that have eco-label including recycled products, companies receiving ISO 14.000 and ISO 26.000.

\subsection{Public Bank Indonesia Initiative on Financial Inclusion}

Public bank has consistently implemented credit financing policies in environmentally friendly business sectors where this has been regulated in internal regulations such as: Credit Credit Policy which prohibits financing for businesses or projects that endanger the environment with Credit Procedure Standard which among others regulates obligations of prospective debtors to submit Environmental Impact Analysis in financing to businesses / industries that are required or Environmental Management and Monitoring Efforts in accordance with applicable laws and regulations.

The Obligations of prospective debtors to submitisepthe results of an assessment of the Company Performance Rating Program in Environmental Management (PROPER) issued by the Ministry of Environment, especially for companies that have an important impact on the environment; has a very large amount of environmental pollution or damage; potential to pollute or damage the environment; registered on the capital market both at home and abroad; export oriented.

After that, Industry Acceptance Criteria Palm Oil which has been updated in several aspects such as not being allowed to distribute peat land financing, both new and existing debtors of public bank; Land area for planted at least 3,000 Ha; preferably land status; Have a Plantation Business Permit; Have a (Standard Operation Procedure) SOP for Prevention and Handling of Land Fires, have standard re-handling equipment in accordance with the criteria of the land and have a special re prevention team that is trained according to the Directorate General of Forestry standards; and Plantation companies with an area of 250 hectares or more must facilitate the development of community gardens around a minimum of $20 \%$ of the total area or as stated in the location permit.

In addition, Public Bank has also formulated the Sustainability Banking Principles, which are all principles of managing bank activities in aspects of Customer, Business Strategy, Banking Operations, Risk Management, Human Capital and Community Development. In one aspect of Risk Management it is stated that the bank considers and mitigates all risks including environmental \& social risks in business activities.

In preparing the Sustainability Financial Action Plan, public bank conducts a review of the

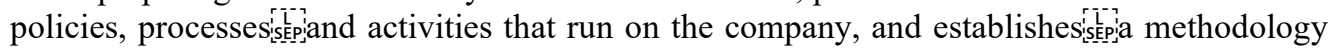
for determining priority sectors and strategies for sustainable financial implementation. The Sustainability Financial Action Plan program will be focused on a 1 (one) year and 5 (five) year program for financing in 4 (four) priority sectors in the Large Corporate segment, which is implemented by preparing investment and financing policies, reporting procedures, and disclosure of the Sustainability Financial Action Plan. These Plan also includes 
Environmental, Social and Governance initiatives on micro banking, as well as the implementation of Corporate Social Responsibility (CSR) activities that meet the concept of sustainable development.

With such coverage, this plan does not merely comply with regulations, but can be a real reference for public banks in implementing sustainable finance, both at the Head Office and in all operational offices throughout Indonesia. Through the plan, banks show its sincerity to realize sustainable development, as well as efforts to control climate change.

\subsection{Public Banks Indonesia on Initiatives Corporate Social Responsibility}

Public banks have creative home is a step taken to support collaboration in forming the Digital Economy Ecosystem through fostering capacity building and capabilities for business start-ups and / or Small and Medium Enterprises (SMEs). This home acts as a data and information center as well as a center for education, development and digitalization (Incubators) for SMEs.

The main objective of establishing creative home is to help access SME marketing in Indonesia through digital e-commerce. It is also useful to improve the quality of SMEs and is expected to have an impact on the progress and improvement of MSME businesses that can create a good Digital Economy Ecosystem. Providing guidance to MSME Partners with a focus on the fashion sector (Weaving, Songket, Batik), Food and Crafts. Coaching for foster partners covering 3 (three) aspects, namely Go Modern, Go Digital, Go Online such as digital marketing training, product design training, training financial management training, digipreneur training, copywriting training. Conducting various exhibitions in national events to introduce products from fostered partners to the general public.

For describing cyber security management activities carried out by public banks untilis: 2019 (both in terms of governance and human resources involved to risk mitigation undertaken) in the 2019 Annual Report and Sustainability Report. It manages cyber security security policies; protection of customer data including modifications; audit (internal and external); IT Committee; and data security awareness policies. The data security provisions in accordance with the data life cycle (create, access, use, store, share \& disposal) no later than December 2020. The management of cyber security four (4) areas, namely the capability of a data security protection; user access management; operational risk management tools; and risk assessment of IT Service Providers.

\subsection{Public Banks Indonesia on Initiatives Green Banking}

Public banks committed to improving environmental and social performance through the transformation of work culture that supports green behavior in operational activities. Activities or programs undertaken include the Green Office Program in the context of efficient use of energy (electricity \& water) and emission reduction.

In 2019, the Bank has made various efforts to save electricity energy, among others by increasing the glass panes in existing buildings, replacing TL lights to LEDs, turning o lights during recess, activating a certain number of elevators during holidays, reducing the use of excess electricity in all unit work, as well as the use of low OTTV (Overall Thermal Transfer Value) glass.

Banks also realizes that the source of clean requires large costs to process raw water into drinkable water, so the Bank implements a water 
saving policy in accordance with Nota No. HBK.CSC/CMA/2019 about eco-friendly action. The bank's efforts to save water include installing recommendations to use water wisely, checking water installations regularly to minimize leakage, and using recycled water, especially at the Head Office. The recycled water is used for various purposes, such as watering plants, cooling air-conditioning water, and water to push the closet. With these various efforts, until December 31, 2019, the Bank has resulted in recycled water by $31 \%$ and reduced the contribution of drinkable water use from $85 \%$ in 2016 to $69 \%$ in 2019 .

After that, the use of environmentally friendly materials, namely the use of glass material that can reduce UV rays and reduce heat absorption in buildings in several existing and currently under construction banks buildings. The separation of plumbing installations for gray water and black water and water recycling systems for processing into clean water again. The installation of solar panels in several existing banks buildings and those being built.

As an initial step, the eco-friendly action will begin to be implemented in the Head Office and several banks areas of the Jabodetabek Region and Kalimantan Region. Green actions taken are: reducing the use of plastic in all work units, among others. bring a personal tumbler at a meeting and provide re 11 drinking water at the meeting; reducing the use of paper in all work units such as actively using email as information sharing and internal meeting invitations, digitizing tools kits \& materials to stakeholders; reducing energy consumption (electricity and water) in all work units such as taking enough water, reporting leakage of taps, turning o lights during recess; and cooperating with all office building managers to separate office waste into 2 (two) and or 3 (three) categories, namely organic, non-organic, and B3 / Toxic Hazardous Materials.

As a form of corporate responsibility in the aspect of environmental sustainability in supporting the sustainable financial agenda, banks implement a Green Campaign. Green Campaign is an activity that aims to educate the public on the importance of maintaining the preservation of nature by utilizing clean and environmentally friendly energy as a form of environmental awareness.

\section{Conclusion}

The study analyzed current policies and implementation status of sustainability in the banking industry of Bangladesh with special reference to Financial Inclusion (FI), Corporate Social Responsibility (CSR), and Green Banking (GB). The study revealed a positive response in implementing the sustainability issues by the banks in various capacities although a little research was done by others on this line. Thus the proposed study is a modest attempt to shed light on the mostly concerned issues of the current time, i.e. sustainability issues in banking industry in Indonesia. Banks are already instructed to follow some of the policy guidelines from the central bank and at the same time banks are also familiar with some of the sustainable products \& services like green banking through technological advancement in the banking operation, environmental risk rating in the process of credit appraisal, diversified deposit \& credit base for banks through the financial inclusion etc.

In Indonesia, there are serious gaps in understanding basic financial concepts and an understanding of the benefits and risks associated with particular financial decisions, including spending, borrowing and saving. Due to lack of appropriate basic financial knowledge/literacy and various regulations of government and law enforcing agencies, people have difficulty in learning about new innovative financial products \& services as well as the consequences of 
violating the rules and regulations related to the financing, social \& environmental aspects. Bank has a financial literacy program using radio, TV and internet to point out some of these knowledge gaps and helped to build awareness in the underprivileged segments of the society.

\section{References}

[1] Adewale MT, Rahmon TA. Does corporate social responsibility improve an organization's financial performance? Evidence from Nigerian banking sec- tor. J Corp Gov 13(4):52-60. (2014).

[2] Abubakar, Lastuti., dan Tri Handayani. Juridical Implication os The Sustainability Finance Principles Implementation in The Banking Sector on the Obligations of Sustainability Reporting. Jurnal Dinamika Hukum, Vol. 19, Issues 1 January 2019. DOI: 10.20884/1.jdh.2019.19.1.2189. (2019).

[3] Ahmad, F., Zayed, N. M., \& Harun, M. A. Factors behind the adoption of green banking by Bangladeshi commercial banks. ASA University Review, 7(2), 241-255. (2013).

[4] Al-Tuwaijri, S. A., Christensen, T. E., \& Hughes, K. The relations among environmental disclosure, environmental performance, and economic performance: A simultaneous equations approach. Accounting, Organizations and Society, 29(5), 447471. (2004).

[5] Berger AN, El Ghoul S, Guedhami O, Roman RA. Internationalization and bank risk. Manag Sci 63:2283-2301. (2017).

[6] Bose, S., Khan, H. Z., Rashid, A., \& Islam, S. What drives green banking disclosure? An institutional and corporate governance perspective. Asia Pacific Journal of Management, 35(2), 501-527. https://doi.org/10.1007/s10490-017-9528-x. (2018).

[7] Bouslah K, Kryzanowski L, M'Zali B. Social performance and firm risk: impact of the financial crisis. J Bus Ethics 149:643-669. (2018).

[8] Brammer, S., \& Pavelin, S. Factors influencing the quality of corporate environmental disclosure. Business Strategy and the Environment, 17(2), 120-136. (2008).

[9] Bryson, D., Atwal, G., Chaudhuri, A., \& Dave, K. Antecedents of intention to use green banking services in India. Strategic Change, 25(5),551-567. https://doi.org/https://doi.org/10.1002/jsc.2080. (2016).

[10] Carney, M. Breaking the Tragedy of the Horizon-climate change and financial stability. Speech given at Lloyd's of London, 29 September 2015.

[11] Callado-Munoz FJ, Utrero-Gonzalez N. Does it pay to be socially respon- sible? Evidence from Spain's retail banking sector. Eur Financ Manag 17:755-787. (2011).

[12] Chen, Y. Green organizational identity: sources and consequence. Management Decision, 49(3),384-404. (2011)

[13] https://doi.org/10.1108/00251741111120761.

[14] Cheng, B., Ioannou, I., \& Serafeim, G. Corporate social responsibility and access to finance. Strategic Management Journal, 35(1), 1-23. (2014).

[15] Cornett MM, Erhemjamts O, Tehranian H. Greed or good greeds: an examination of the relation between corporate social responsibility and the financial performance of U.S. commercial banks around the financial crisis. J Bank Financ 30:137-159. (2016).

[16] Cull R, Demirgüç-Kunt A, Lin JY. Financial structure and economic development: a reassessment. World Bank Econ Rev 27:470-475. (2013) 
[17] Dafermos Y, Nikolaidi M, Galanis G. Climate change, financial stability and monetary policy. Ecol Econ 121:219-234. (2018).

[18] Dangelico, R. M., \& Pujari, D. Mainstreaming green product innovation: Why and how companies integrate. Journal of Business Ethics, 95, 471-472. (2010). https://doi.org/10.1007/s10551-010-0434-0.

[19] Dhaliwal, D. S., Li, O. Z., Tsang, A., \& Yang, Y. G. Voluntary nonfinancial disclosure and the cost of equity capital: The initiation of corporate social responsibility reporting. The Accounting Review, 86(1), 59-100. (2011).

[20] Dixit, AK. How business community institutions can help fight corruption. World Bank Econ Rev 29: 25-47. (2015).

[21] Dorfleitner G, Halbritter G, Nguyen M. Measuring the level and risk of corporate responsibility: an empirical comparison of different ESG rating approaches. J Asset Manag 16:450-466. (2015)

[22] Friede G, Busch T, Bassen A. ESG and financial performance: aggregated evidence from more than 2000 empirical studies. J Sustain Financ Invest 5:210-233. (2015).

[23] Galaz V, Crona B, Dauriach A, Scholtens B, Steffen W. Finance and the Earth systemexploring the links between financial actors and non-linear changes in the climate system. Glob Environ Change 53:296-302. (2018).

[24] Handajani, L., Rifai, A., \& Husnan, L. H. Kajian tentang inisiasi praktik green banking pada bank BUMN. Jurnal Economia, 15(1), 1-16. (2019).

[25] Haniffa, R. M., \& Cooke, T. E. The impact of culture and governance on corporate social reporting. Journal of Accounting and Public Policy, 24(5), 391-430. (2005).

[26] Heal, G. When Principles Pay. Colombia Business School, New York. (2008).

[27] Hooks, J., \& van Staden, C. J. Evaluating environmental disclosures: The relationship between quality and extent measures. The British Accounting Review, 43(3), 200-213. (2011).

[28] Hossain, D. M., Bir, A. T. S. Al, Abdul, K. M. T., \& Momen, A. Disclosure of green banking issues in the annual reports: A study on Bangladeshi banks. Middle East Journal of Business, 11(1), 19-30. (2016).

[29] https://doi.org/10.5742/MEJB.2015.92758

[30] Hussain, N., Rigoni, U., \& Orij, R. P. Corporate governance and sustainability performance: Analysis of triple bottom line performance. Journal of Business Ethics. (2016). https://doi: 10.1007/s10551-016-3099-5

[31] Jeucken, M. Sustainability in Finance: Banking on Planet, Eburon Academic Pubisher, The Netherlands. (2004)

[32] Kamal, M. The role of corporate social responsibility (CSR) in the Egyptian Banking Sector. Working paper. Federal Reserve Bank of St. Louis. (2013).

[33] Kemp-Benedict E. Investing in a green transition. Ecol Econ 153:218-236. (2018).

[34] Keys PW, Galaz V, Dyer M, Matthews N, Folke C, Nyström M, Cornell S.. Anthropocene risk. Nat Sustainability. (2019).

a. https://doi.org/10.1038/s41893-019-0327-x

[35] Laeven L, Levine R. Bank governance, regulation and risk taking. J Financ Econ 93:259-275. (2009).

[36] Lopatta, K., Buchholz, F., \& Kaspereit, T. Asymmetric information and corporate social responsibility. Business \& Society, 55(3), 458-488. (2016).

[37] Malik, MS, Nadeem M. Impact of corporate social responsibility on the financial performance of banks in Pakistan. Int Lett Soc Humanist Sci 21:9-19. (2014). 
[38] Maryanti, Rahmatia, Nursini, \& Sanusi Fattah. Measuring Sustainability Development Index in Indonesia. International Journal of Innovative Science and Research Technology, Vol. 5, Issues 2, February:52-60. (.2020).

[39] Menassa E. Corporate social responsibility. An exploratory study of the quality and extent of social disclosures by Lebanese commercial banks. J Appl Account Res 11:423. (2010).

[40] Ong, T. S., Soh, W. N., Teh, B. H., \& Ng, S. H. Influence of environmental disclosures on the financial performance of public listed Malaysian manufacturing companies. Asia-Pacific Management Accounting Journal, 10(1), 107-136. (2016).

[41] Paulik J, Majková MS, Tykva T, Cervinka M. Application of the CSR measuring model in commercial banking in relation to their financial performance. Econ Sociol 8:64-81. (2015).

[42] Roy, Mihir Kumar., Md. Abdus Salam Sarker, dan Shahriar Parvez. Sustainability in Banking Industry: Which Way to Move? ASA University Review, Vol. 9, No. 2, JulyDecember. (2015).

[43] Ramiah, V., Morris, T., Moosa, I., Gangemi, M., \& Puican, L. The effects of announcement of green policies on equity portfolios: Evidence from the United Kingdom. Managerial Auditing Journal, 31(2), 138-155. (2016).

[44] https://doi.org/10.1108/MAJ- 08-2014-1065.

[45] San, O. T. Influence of environmental disclosures on the financial performance of public listed Malaysian manufacturing companies. Asia- Pacific Management Accounting Journal, 10(1), 107-136. (2016).

[46] Saxena M, Kohli AS. Impact of corporate social responsibility on corporate sustainability: a study of the Indian banking industry. J Corp Gov 11(4):1-16. (2012).

[47] Semenova N, Hassel LG. On the validity of environmental performance metrics. J Bus Ethics 132:249-258. (2015)

[48] Scholtens, B. Financial and social performance of socially responsible investments in the Netherlands. Corp Gov 15:1090-1105. (2007).

[49] Scholtens, B. Why finance should care about ecology. Trends Ecol Evol 32:500-505, (2017).

[50] Simpson G, Kohers T. The link between corporate social and financial performance: evidence from the banking industry. J Bus Ethics 35:97-109. (2002).

[51] Sun W, Cui K. Linking corporate social responsibility to firm default risk. Eur Manag J 32:275-28. (2014).

[52] Thompson, P., \& Cowton, C. J. Bringing the environment into bank lending: Implications for environmental reporting. The British Accounting Review, 36, $197-$ 218. (2004).

[53] https://doi.org/10.1016/j.bar.2003.11.005

[54] Unerman, J. Methodological issues- reflections on quantification in corporate social reporting content analysis. Accounting, Auditing\& Accountability Journal, 13(5), 667681. (2000).

[55] Uddin S, Islam MZ, Hasan I. Corporate social responsibility and financial performance Linkage-Evidence from the banking sector of Bangladesh. J Organ Manag 1:14-21. (2012).

[56] Zahid, M., \& Ghazali, Z. Corporate sustainability practices among Malaysian REITs and property listed companies. World Journal of Science, Technology and Sustainable Development, 12(2), 100-118. (2015). 